\title{
電気式床暖房室内の熱放射場に関する実験的研究 \\ EXPERIMENTAL STUDY ON THERMAL RADIATION FIELD IN A ROOM WITH ELECTRIC FLOOR HEATING
}

\author{
百家裕季*, 中村泰人**, 岡本孝美***, 天川章史 ${ }^{* * * *}$ \\ Hiroki MOMOKA, Yasuto NAKAMURA, Takami OKAMOTO \\ and Akifumi AMAKAWA
}

\begin{abstract}
Thermal radiation field in a room with electric floor heating was investigated by experiments using a cubic net radiometer. The surface temperature of the floor was set at a high temperature of 50 degree centigrade at the highest, for the sake of conducting an evaluation method of thermal environment in the room with floor heating. The height of measurement was selected at $50 \mathrm{~cm}$ above the floor corresponding to the posture of a human body sitting on the floor. Using the cubic net radiometer made it possible to analyze the variation of thermal environment in the room owing to the directionality of the instrument.
\end{abstract}

Keywords: cubic net radiometer, floor heating, instrumentation, experiment, surface temperature, thermal radiation field 立方体正味放射計、床暖房、計測法、実験、表面温、熱放射場

\section{1. はじめに}

空間中に放射性媒質を含むか研かにかかわらず、境界面上および 空間中のある点では、その温度に基づいて周囲のあらゆる方向一放 射を発散すると同時に、周囲のあらゆる方向から放射を受けて吸収 することを、放射伀熱学 ${ }^{11}$ は教えている。これら空間中における熱 放射の複雑な流れの状態は、熱放射場2) 3) と捉えられる。

熱放射場では一般に、温度に高低差があると無数の放射の流れに 方向性が生じる。放射の方向性を示すには放射束ベクトル4) の表現 が最適である。放射束ベクトルの各成分から人体に対する平均放射 温度が表現できることは、すでに指摘 ${ }^{3)}$ されている。放射束べクト ルは、立方体正味放射計 ${ }^{5)}$ を用いた測定で得ることができる。注1)

さて近年、暖房システムとして床暖房が普及してきたが、床暖房 によって形成される室内の熱環境は、設計に結びつくような評価が なされることなく、今日に及んでいる。とくに床暖房は通常の暖房 方式と異なっていて、一般的な熱環境指標である SET* や PMV で は十分に表せないのが課題である。それゆえ、快適性や安全性のみ ならず、省エネルギ一性の観点からも、設計に適用できる床暖房評 価法の確立が望まれている6”。

しかしながら、床暖房が他の暖房システムと性質を異にするとい っても、形成された熱環境の評価には、他のシステムとの比較を可 能にする必要があるから、熱環境の物理的な諸量の計測が基本にな ることは論をまたない。そこで本研究では、林爰房による室内熱環 境の適切な評価法を導出することを目標としつつ、関係する物理的
な諸量、とくに放射の方向性を中心にして、床暖房によって生じた 熱放射場を実験的に精查することを目的とするものである。

熱放射場の測定には、一般にグローブ温度計が用いられるが、そ れで平均放射温度が得られるとしても、時定数が大きいために測定 精度が劣り、しかも放射の方向性が不明であるから、それ以上に分 析が進まない。その欠点に拘束されないように、本研究ではグロー ブ温度計に代わって立方体正味放射計を用いた。

なお、表題で電気式床暖房と称しているが、これは実験対象とし た床暖房が電気式床暖房であり、電気式に固有の変動が忠実に計測 できたことから電気式床暖房と記したにすぎない。一般的な研究結 果は電気式床暖房にかぎらず、温水式床暖房にも適用できる。 本論文は、既発表文献7) を基に加筆構成したものである。

\section{2. 研究方法}

\section{1 実験対象室}

実験の対象とした室は、図 1 に示すように、平面 $4.5 \mathrm{~m} \times 6.0 \mathrm{~m}$ 、天 井高 $2.45 \mathrm{~m}$ の室で、1 短辺側が南に面し、南面にはガラス空があっ てカーテンがかけられている。対する北側の辺は一部に開口を通じ てキッチンにつながっている。すなわち、住宅のやや大型の LDK の造りである。

床は、表面はすべてフローリング仕上げで、その裏側に電気暖房 パネルが設置されている。電気パネルは、 1 枚の大きさが $303 \mathrm{~mm} \times$ $1818 \mathrm{~mm}$ であり、連続した千鳥配置として室の中央部 $3636 \mathrm{~mm} \times$

\footnotetext{
* 熊本県立大学大学院環境共生学研究科 学生

** 能本県立大学環境共生学部 教授・工博

*** 熊本県立大学環境共生学部 助手・工修

**** 関西電力㑣エネルギー利用技術研究所 主任研究員
}

Graduate Student, Graduate School, Prefectural University of Kumamoto Prof., Prefectural University of Kumamoto, Dr. Eng. Assistant, Prefectural University of Kumamoto, M. Eng. The Kansai Electric Power Co., Inc. 
4848mm を占めている。床面の裏側は高断熱仕上げとなっている。 西壁と東壁はともに 1 筒所、隣室につながる扉があるほかは開口 部がなく、壁は高断熱構造である。天井は石膏ボード仕上げで、蛍 光灯の丸型の照明器具が 2 個、取り付けられている。

\section{2 立方体正味放射計を用いた計測法}

立方体正味放射計を用いた通常の計測法は、人体形状を立方体で 置き換えることを想定し、成人の立位形状に対して、立方体の中心 の高さを床上 $100 \mathrm{~cm}$ に設定している。しかし、住宅などの床暖房で は膝を折り曲げて床に直接座る座位の場合が多く、そこに床暖房の 特徴があると考えらえる。したがって、床暖房の計測では床座の形 状を想定して、立方体の中心高さを床上 $50 \mathrm{~cm}$ に設定するのを原則 とした。注2)、注3)

立方体正味放射計の設置は、写真用の三脚をはずして 1 本ずつを 立方体の四隅から下方に伸ばし、床上 $100 \mathrm{~cm}$ 測定では床面での足の 間隔が $100 \mathrm{~cm}$ になるよう、床上 $50 \mathrm{~cm}$ 測定では間隔が $50 \mathrm{~cm}$ になる よう、それぞれ固定して設置した。写真 1 に計測状況を示す。

放射場が平面上でどのような空間分布をしているかを知るため、 床面の短辺と長辺をそれぞれ 6 等分し、交点の 25 点を測定候補点と して番号をつけた。南東の隅の点を P1 として西方へ順次移動し、 行を換えて最後に北西隅の点 P25 にいたる順である。実際の空間分 布測定では、室中央点 $\mathrm{P} 13$ を含む奇数の 13 点、または 5 点 (P13, P3, P15, P23, P11 の順）を使用した。図 1 中に測定点の位置を示す。

立方体正味放射計の近傍の気温は、立方体の下方で直径 $0.076 \mathrm{~mm}$ の $\mathrm{T}$ 型極細熱電対を用いて測定している ${ }^{8)}$ 。

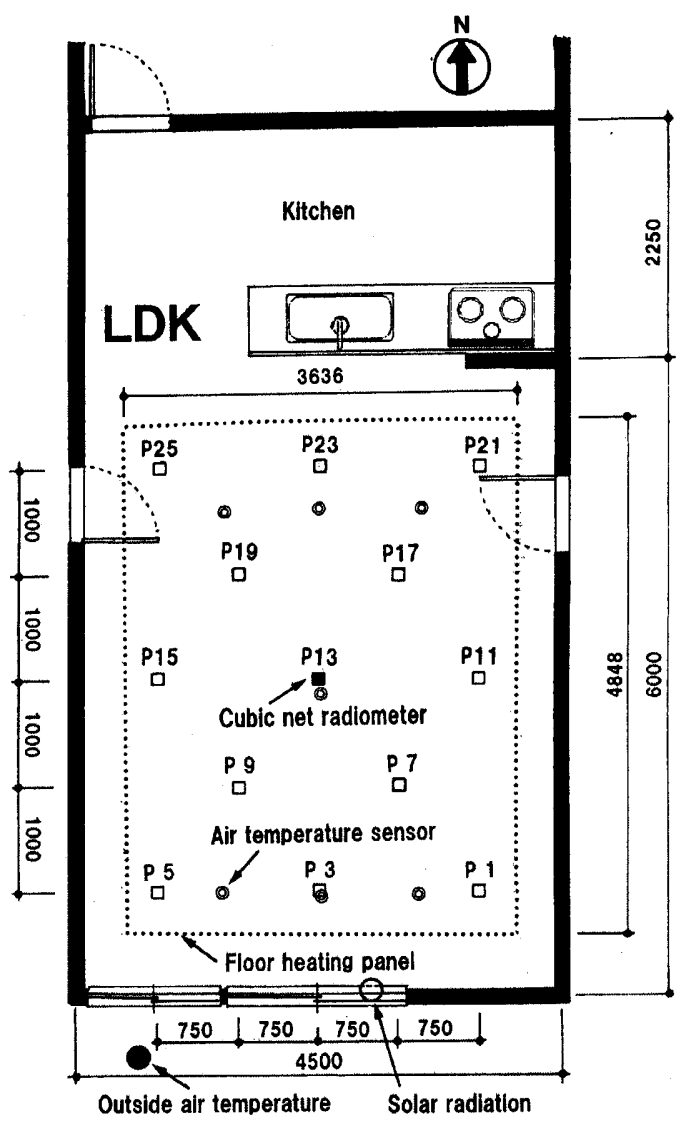

図 1 床暖房室の概要、熱放射場の測定点、室内気温の測定位置

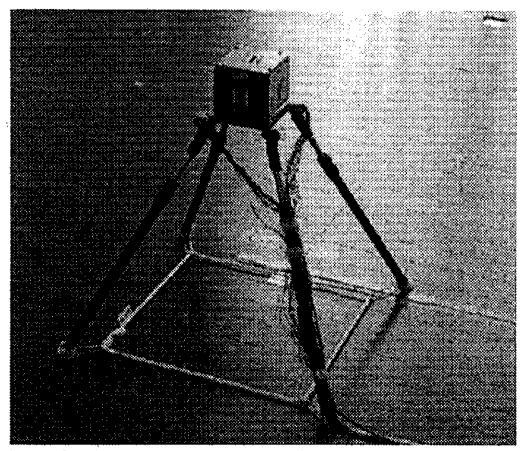

写真 1 床座を対象とした立方体正味放射計の計測状況 (床上 $50 \mathrm{~cm}$ )

\section{3 関連測定項目}

図 1 に示すように、室内気温の測定は床上 $1.2 \mathrm{~m}$ の高さ、室平面 内 7 点において、直径 $0.2 \mathrm{~mm}$ の $\mathrm{T}$ 型熱電対に、放射防護のためにア ルミア䈃でカバーをして行った。以下、断らないかぎり、室内気温 は 7 点の平均を表す。外気温は南空の外側で、直径 $0.076 \mathrm{~mm}$ の T 型極細熱電対を使用した ${ }^{8)}$ 。別に天気概況を知るため、南に面した 空ガラスの窒内側と閉じたカーテンの間のわずかな空間に日射計を 置いて、水平面日射量を測定した。

床表面温は、監視目的で常時 1 箅所において、熱画像式放射計で 測定を続けた。室内の湿度や風速も測定しているが、一般に寒冷環 境では湿度や風速は温熱環境評価にあまり効かないので、本研究で もそれらの測定結果は分析に使用していない。

\section{4 実験条件}

電気式床暖房の運転方式は「弱」または「強」の2 種類で、通常 は 10 時から運転開始、17 時終了であり、2 日連続運転も行った。計 測中は、カーテンは閉じた状態とし、点灯による熱的影響を避ける ために室内の照明器具は消灯した。また、室内で一定の換気を確保 するため、キッチンの排気ファンを常時「弱」で運転した。

実験中の設定温度は、床を含む壁面の各部位間の温度差が大きい ほうが明確な分析が可能なため、特別な温度制御はせずに成り行き まかせとした。

計測時期は 2003 年 11 月 27 日〜 12 月 3 日、天候は最り、このと

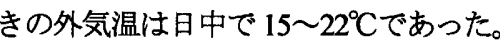

\section{3. 実験結果の表示方法}

\section{1 立方体表面の放射受熱量の表示}

本研究では、冒頭に述べた放射束ベクトルでなく、放射受熱量べ クトルで取り扱うこととする。ベクトルの成分について、放射束は 発散量を正とするのに対して、放射受熱量では逆に受熱量を正とす るところが異なっている。

立方体正味放射計の各表面の中央のセンサーがある面、すなわち 受熱面で、単位面積当たりに吸収する熱量を $q_{k}\left[\mathrm{~W} \mathrm{~m}^{-2}\right]$ とすると、 $q_{k}$ は次式で表される。

$$
q_{k}=a_{s} I+\varepsilon_{s} \sigma\left(T_{r}^{4}-T_{s}{ }^{4}\right)+\alpha_{c}\left(T_{a}-T_{s}\right)
$$

ここで、I $\left[\mathrm{W} \mathrm{m}^{-2}\right]$ が受熱面における日射の受熱量（吸収する熱量 ではなく面に当たる直前の熱量)、 $\sigma T_{r}^{4}\left[\mathrm{~W} \mathrm{~m}^{-2}\right]$ が長波長放射の受 熱量である。その他の記号は、つぎのとおりである。

$T_{r}$ ： 受熱面での面放射温度 ${ }^{9)}[\mathrm{K}]$ 

$T_{a}$ ： 受熱面の周辺気温 [K]
$T_{s}$ ：受熱面の表面温度 $[\mathrm{K}]$
$a_{s}$ ：受熱面の日射の吸収率（波長範囲 $0.3 \sim 3.0 \mu \mathrm{m}$ ）
$\varepsilon_{\varepsilon}$ : 長波長放射の放射率（波長範囲 3 100 $\mu \mathrm{m}$ ) Kirchhoff の法則により、長波長放射の放射率=吸収率
$\sigma$ : Stefan-Boltzmann 定数 $5.67 \times 10^{-8}\left[\mathrm{~W} \mathrm{~m}^{-2} \mathrm{~K}^{-4}\right]$
$\alpha_{c} ：$ 受熱面の対流熱伝達率 $\left[\mathrm{W} \mathrm{m}^{-2} \mathrm{~K}^{-1}\right]$

\section{2 面放射温度と日射による面放射温度の表示}

平面での放射受熱量は、Stefan-Boltzmann の法則にしたがって、そ れと同量の黒体放射に置き換えたとき、黒体の温度を面放射温度 $\mathrm{PRT}^{9)}$ と乎んでいる。長波長放射による面放射温度は式 (1) に示し たとおりであるが、日射についても面放射温度で表すことができれ ば、長波長放射と同じ温度の単位の表示となるので、比較ができて 好都合である。しかし、日射について面放射温度で表すためには工 夫を要する。注4)

まず、式 (1) の放射の項をつぎのように変形すると、 $\boldsymbol{\kappa}_{m}$ はほぼ 定数とおくことができる ${ }^{10)}$ 。

$$
\begin{aligned}
& \varepsilon_{s} \sigma\left(T_{r}{ }^{4}-T_{s}{ }^{4}\right)=\varepsilon_{s} \kappa_{m}\left(T_{r}-T_{s}\right) \\
&=\alpha_{r}\left(t_{r}-t_{s}\right) \\
& \alpha_{r}=\varepsilon_{s} \kappa_{m} \risingdotseq \varepsilon_{s} \times 4 \sigma T_{m}{ }^{3} \\
& T_{m}=\left(T_{r}+T_{s}\right) / 2
\end{aligned}
$$

この関係を用いると、式 (1) は式 (5) に変わる。

$$
q_{k}=\left(\alpha_{r}+\alpha_{c}\right)\left[\left[\alpha_{r}\left(t_{r}+t_{i}\right)+\alpha_{c} t_{a}\right] /\left(\alpha_{r}+\alpha_{c}\right)-t_{s}\right] \cdots
$$
ここに、

$t_{i}=\left(a_{s} / \alpha_{r}\right) I$

$t_{r} \quad$ : 受熱面での長波長放射の面放射温度 $\left[{ }^{\circ} \mathrm{C}\right]$

$t_{i} \quad$ : 新しく定義された日射による面放射温度 $\left[{ }^{\circ} \mathrm{C}\right]$

$t_{a}$ : 受熱面の周辺気温 $\left[{ }^{\circ} \mathrm{C}\right]$

$t_{s} \quad$ : 受熱面の表面温度 $\left[{ }^{\circ} \mathrm{C}\right]$

$\alpha_{r} ：$ 受熱面の放射熱伝達率 $\left[\mathrm{W} \mathrm{m}^{-2} \mathrm{~K}^{-1}\right]$

である。

いま、代表的な値として、関係する面の平均温度 $T_{m}=295[\mathrm{~K}]$ 、 日射の吸収率 $a_{s}=0.5$ 、長波長放射の放射率 $\varepsilon_{s}=0.95$ 、を与えると、 式 (6) はつぎの関係における。

$$
t_{i}=0.09 I
$$

式 (7) は日射量 $\left[\mathrm{Wm}^{-2}\right]$ から面放射温度 $\left[{ }^{\circ} \mathrm{C}\right]$ を求める換算式 である。日射による面放射温度は、近似的であるが日射量 $\left[\mathrm{W} \mathrm{m}^{-2}\right]$ の 0.09 倍を温度 $\left[{ }^{\circ} \mathrm{C}\right]$ で表せばよいこととなる。

測定を行おうとする面の日射の吸収率が 0.5 と明らかに異なる 場合は、式 (6) に基づいて式 (7) を修正して用いる必要がある。な ぜなら、日射による面放射温度は受熱面で吸収した成分を含んでい るからである。

\section{3 ベクトル嘼の表示}

立方体正味放射計を用いた測定で得られる立方体各面における受 熱量（面放射温度も同様）は、ベクトル量の成分に相当する。すな わち、 $x y z$ の直角座標において、

$$
\begin{array}{lll}
q_{+x} & : & x \text { 軸の正方向の面の放射受熱量 }\left[\mathrm{W} \mathrm{m}^{-2}\right] \\
q_{-x} & : & x \text { 軸の負方向の面の放射受熱量 }\left[\mathrm{W} \mathrm{m}^{-2}\right]
\end{array}
$$

（ $y$ 軸、 $z$ 軸についても同様に表される）

$q$ ： 正味放射受熱量ベクトル

$\boldsymbol{i}, \boldsymbol{j}, \boldsymbol{k}$ ： 単位ベクトル

とおくと、正味放射受熱量ベクトルは、

$q=\left(q_{+x}-q_{-x}\right) \boldsymbol{i}+\left(q_{+y}-q_{-y}\right) \boldsymbol{j}+\left(q_{+z}-q_{-z}\right) \boldsymbol{k}$

で表される。大きさ $|q|$ と方向余弦 $l_{x}, l_{y}, l_{z}$, は、

$$
\begin{aligned}
& |q|=\left[\left(q_{+x}-q_{-x}\right)^{2}+\left(q_{+y}-q_{-y}\right)^{2}+\left(q_{+z}-q_{-z}\right)^{2}\right]^{1 / 2} \cdots(10) \\
& l_{x}=\left(q_{+x}-q_{-x}\right) /|q| \\
& l_{y}=\left(q_{+y}-q_{-y}\right) /|q| \\
& l_{z}=\left(q_{+z}-q_{-z}\right) /|q|
\end{aligned}
$$

で表される3゙。

しかし、ベクトル量の表示として、大きさと方向余弦では直観的 な理解にそしいので、それとは別にベクトル量の表示には、水平面 における $x$ 軸、 $y$ 軸の原点から離れる距離と角度、及び $x$ 軸（南北 軸）を含む垂直面と $y$ 軸（東西軸）を含む垂直面の、両垂直面での 座標軸の原点からの距離と角度で表すこととした。

なお、べクトル量の大きさとは正味放射量であり、それは空間中 における放射の方向性を表す量である。大きさが 0 の場合は放射に 方向性がないこと、すなわち対称性、等方性であることを示す。

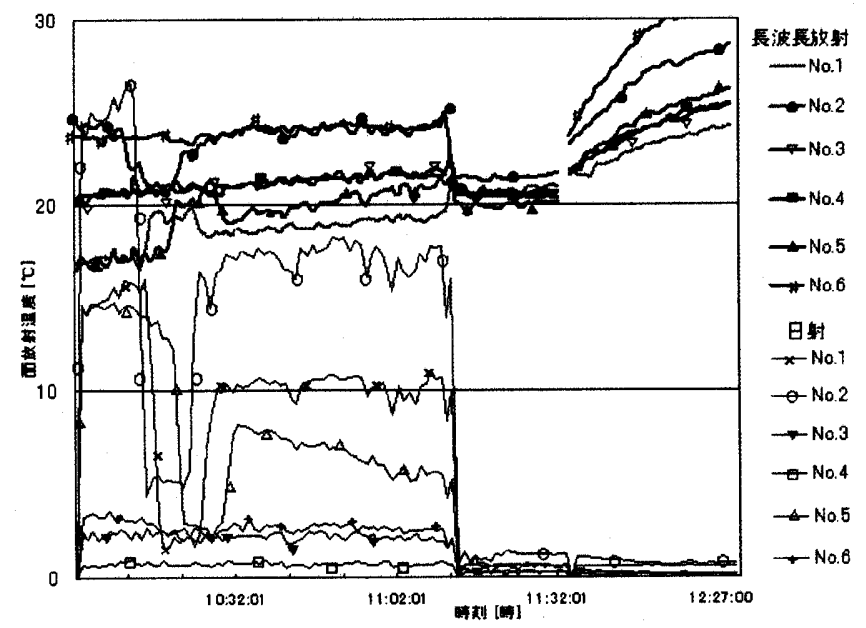

図 2 立方体正味放射計を用いて得られた立方体各面 の面放射温度（11月26日，P13，床上 $50 \mathrm{~cm} ）$

\section{4. 結果と考察}

\section{1 室内の熱放射場に及ぼす日射の効果}

図2は、室内に置かれた立方体正味放射計に日射が当たっている 状態での観測例である。図中の細線が日射による、太線が長波長放 射による、それぞれ面放射温度である。測定点は室中央 P13 で床上 $50 \mathrm{~cm}$ の高さ、南空のカーテンは 11:13 まで開放、それ以降は閉鎖で あった。結果は、直射のために立方体表面の No.2 面（南向き面）で 最も日射の值が大きく、最大で $20^{\circ} \mathrm{Cを}$ 超えている。これは、後述す る (4.3) 床暖房の有効面放射温度 (床暖房面に対する面放射温度と 室内気温との差) の最高 $11^{\circ} \mathrm{C}$ り大きい。このように、日射の効果 は相当に大きい。一方、11:13にカーテンを閉じると、日射による面 放射温度は急激に下がり、No.2 面で $1^{\circ} \mathrm{C}$ 程度、他はそれ以下となる。 長波長放射による面放射温度は、床暖房開始前では 20 2 $22^{\circ} \mathrm{C}$ 程度で あるから、カーテンによる日射遮蔽効果の大きいことがわかる。こ 
の結果に基づいて、実験中は常時カーテンを閉鎖することとした。 このように、日射による面放射温度は長波長放射による面放射温度 に比して無視できるほど小さいので、以下では長波長放射を中心に 考察することとした。なお、図中の 11:33に長波長放射による面放 射温度が急激に上昇をはじめるのは、床暖房が開始したことによる 応答である。

図中の面放射温度に対応した番号は立方体の面の番号で、面の向 きはつぎのとおりである。

$\begin{array}{llllll}\text { No.1 } & \text { 上向き } & \text { No.2 } & \text { 南向き } & \text { No.3 } & \text { 西向き } \\ \text { No.4 } & \text { 北向き } & \text { No.5 } & \text { 東向き } & \text { No.6 } & \text { 下向き }\end{array}$

ただし、鉛直面は室の壁面に平行または直角とした。

\section{2 床暖房「弱」運転時の熱放射場の挙動}

図了は、床暖房の「弱」運転時における熱放射場の経時変化を、 面放射温度で示したものである。あわせて室内気温、カーテン外側 の水平面日射量、および外気温を示す。立方体正味放射計を設置し た位置は、原則として室中央点 $\mathrm{P} 13$ 、床上 $50 \mathrm{~cm}$ である。ただし、 11 時、13 時、16 時からの 1 時間は熱放射場の空間分布を知るため、 12 分ごとに 5 箇所、計測器の位置を変えた。12 分のうち、2 分は移 動時間にあて、データ表示に 10 分をあてている。計測器の時定数は 約 10 秒と短いため、2 分以内で他に影響を及ぼすことなく、位置の 変更とセットが可能であった。なお、計測方式は、データロガーで 6秒ごとにデータを収録し、ロガー内で 1 分間の平均演算を行い、 1 分ごとに結果をディスクに記録する方式である。

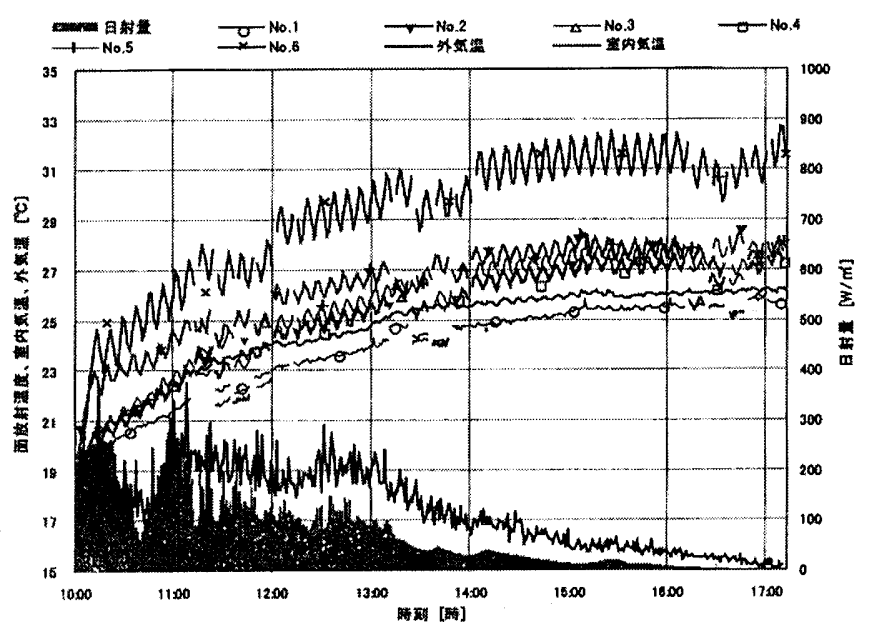

図 3 「弱」運転時の立方体各表面の面放射温度 の経時変化 $(11$ 月 27 日，床上 $50 \mathrm{~cm})$

図3では、No.6面の周期的な変動が注目される。これは「弱」運 転では 4 分ごとに電流の $\mathrm{ON} / \mathrm{OFF}$ を繰り返しているため、その影響 が面放射温度にも表れたことを示している。変動の振幅の大きさは 面によって違いがあり、No.6 面が最大振幅を示すのは、加熱された 床面を大きく見るためである。実測によれば、No.6 面から床暖房パ ネルを見る形態係数は 0.960 であった。逆に、No.1 面は床面が視野 に入っていないので変動がないと思われたが、実際にはわずかに周 期的変動が認められる。これは、室内気温にもわずかな変動が見ら れることから、4 分ごとの ON/OFFに対応して、天井温や気温にも わずかに周期的変動が及んでいたものと解される。立方体の他の鉛
直の 4 面では、変動の振幅はNo.6 面の約半分となっているから、こ れも同様に理解できるところである。

運転を開始してから 6 時間後（16:00）には、室内気温が $26.0^{\circ} \mathrm{C}$ と

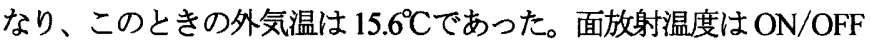
平均して最高で $31.77^{\circ} \mathrm{C}$ 、最低で $25.5^{\circ} \mathrm{C}$ なった。振幅は最高で $0.8 \mathrm{~K}$ である。参考までに熱画像式放射計で計った床表面温は最高で $37^{\circ} \mathrm{C}$ であった。

立方体の各面で面放射温度の違いはかなり大きく、6 時間後に、

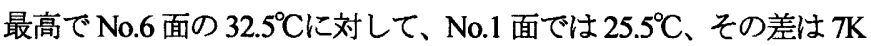

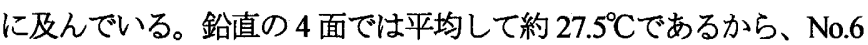
面との差は $2 \mathrm{~K} て ゙ 、 N o .6$ 面だけが著しく高くなっていることがわか る。これらの面放射温度から平均放射温度を求めてみると $28.0^{\circ} \mathrm{C}$ と なり、室内気温より $2 \mathrm{~K}$ 高いという結果である。

測定点の場所による違いは、離れた 5 点の空間分布で見るかぎり では、面の向きの違いにくらべると大きいとはいえない。

注目されるのは、10 時から 13 時にかけて、No.2 面の面放射温度 が他の鉛直面の面放射温度よりも明らかに高い值を示していること である。これは、このときの日射量も同時に他より若干大きい值を 示していることと、実測によると No.2 面からカーテンのかかった南 空面を見る形態係数が 0.262 と比較的大きい值を示している（ちな みに天井を見る形態係数は 0.162）ことから、日射が空ガラスを透過 してカーテンで吸収され、カーテンの表面温度が上昇したことが原 因として考えられる。日射の効果はこのように、長波長域で影響を 及ぼすことに留意する必要がある。

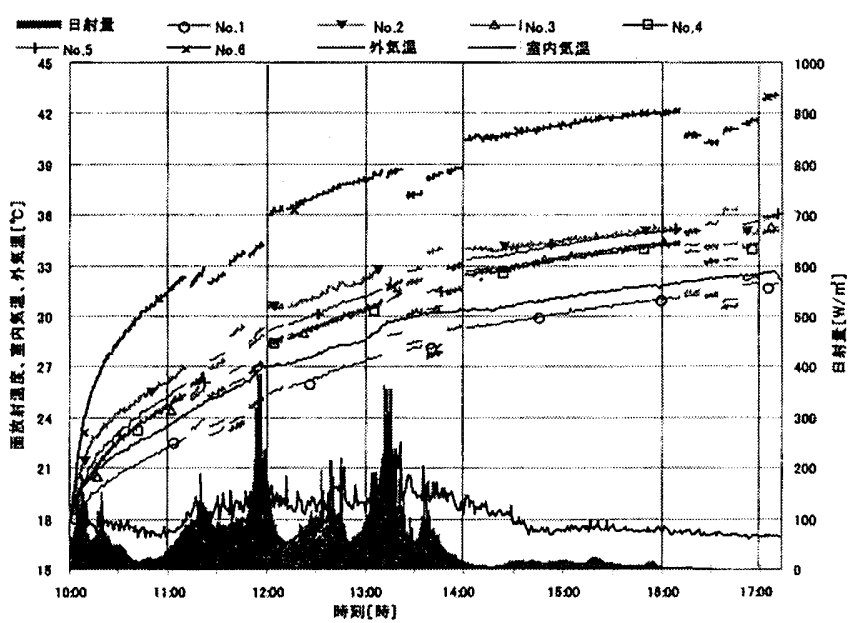

図 4 「強」運転時の立方体各表面の面放射温度 の経時変化 $(11$ 月 28 日, 床上 $50 \mathrm{~cm})$

\section{3 床暖房「強」運転時の熱放射場の挙動}

図4は、床暖房の「強」運転時における室中央測定点 P13 を中心 として、床上 $50 \mathrm{~cm}$ の熱放射場の経時変化を示したものである。

常時通電のため、長波長放射の面放射温度には「弱」運転時のよ うな周期的変動はなくなり、時間とともになだらかな上昇に変わっ ている。6 時間経過後（16:00）には室内気温が $32^{\circ} \mathrm{C}$ とな、外気温

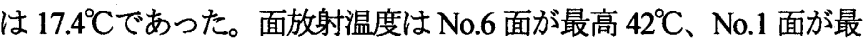
低 $31^{\circ} \mathrm{C}$ であった。したがって、林面に対する面放射温度と室内気温

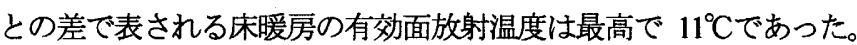
平均放射温度は $35^{\circ} \mathrm{C}$ となり、室内気温より $3 \mathrm{~K}$ 高い值であった。 
指示值が高いことと周期的変動がないことを除いて、「弱」運転で 見られた諸特性は「強」運転でもほぼ同様に見られる。しかしなが ら、変動の時間経過が滑らかであるために、日射の変動が外気温や 面放射温度にまで影響を及ぼしていることを見ることができる。

日射量の変動は、一時的に高い值を示す $11: 20$ 頃、11:55 頃、12:40 頃、13:15 頃に、外気温がピーク值を示すことと対応している。対 応することの理由としては、日射量が増大したために建物外表面の 温度が上がり、それにともなって付近の気温が上昇したことが考え られる。

長波長放射の面放射温度については、立方体の No.2 面の值が 11:20 頃、11:55 頃、12:40 頃、13:15 頃に日射量の変動と呼応して変 動している。これは「弱」運転のところで説明したように、カーテ ンによる日射の吸収と再放射によるものである。

\section{4 面放射温度の測定点による違い}

熱放射場の空間分布の測定には、合計 13 の測定点を使用した。測 定時間は、一巡して最初の点に戻るものを含めて、全部で 14 点の測 定に 2 時間 48 分を要した。この時閒中における変動が少しでも安定 するように、床暖房は「強」で前日より連続運転とし、2 日目に実 験を行った。すなわち、12 月 3 日の 9:00 から床上 50cm の計測、13:00 から床上 $100 \mathrm{~cm}$ の計測である。測定点の計測の順序は、奇数の若い 番号P1 から P25 の順で、最後にP1 に戻る。

図 5に、午前中の床座人体に対応した立方体表面での面放射温度 （床上 $50 \mathrm{~cm}$ ）の測定点による違いを、図6に、午後の立位人体に対 応した面放射温度（床上 $100 \mathrm{~cm}$ ）の測定点による違いを示す。

日射量の変動から見る天気概況は、9:00〜 13:52 までは晴れ、以後 は量りであった。この間に室内気温は、午前中は $34.5 \sim 37.5^{\circ} \mathrm{Cまで}$ 上昇し、午後は $13: 00$ 以降、37.7 $35.5^{\circ} \mathrm{C}$ 範囲で、日射量変動と対 応するように降下した。それに応じて立方体各面の面放射温度も変 化している。この変化から、前述したカーテンの日射による長波長 放射の効果を、さらにまた気温にも効果を及ぼしていることを、見 ることができる。各面の面放射温度の違いは、下向き（No.6）が最 高の值で、床上 $100 \mathrm{~cm}$ より床上 $50 \mathrm{~cm}$ で大きい值を示す。しかし、 測定点の違いによる空間分布は大きくないことがわかる。

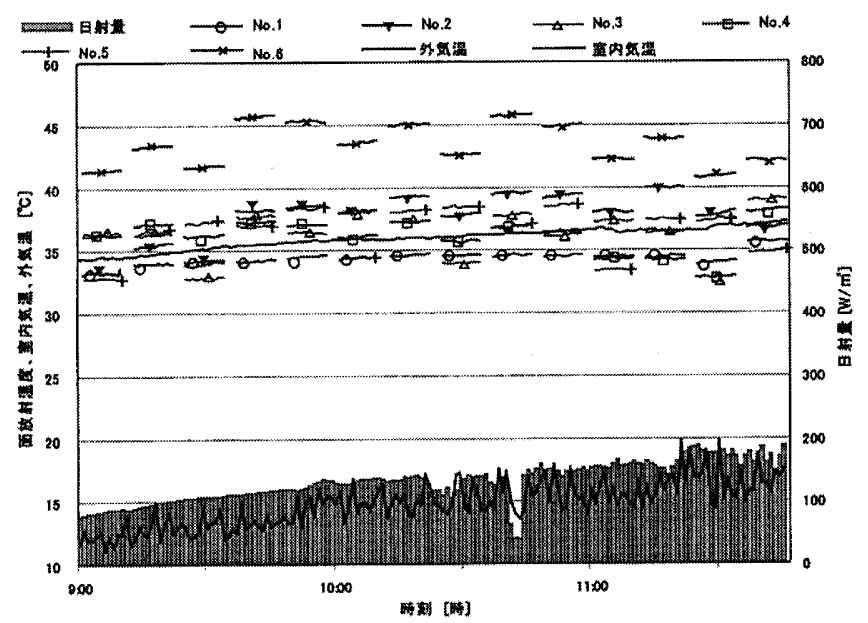

図 5 立方体各表面の面放射温度の室内空間分布

$(12$ 月 3 日, 床上 $50 \mathrm{~cm}, \mathrm{P} 1 \rightarrow \mathrm{P} 25$ の順)

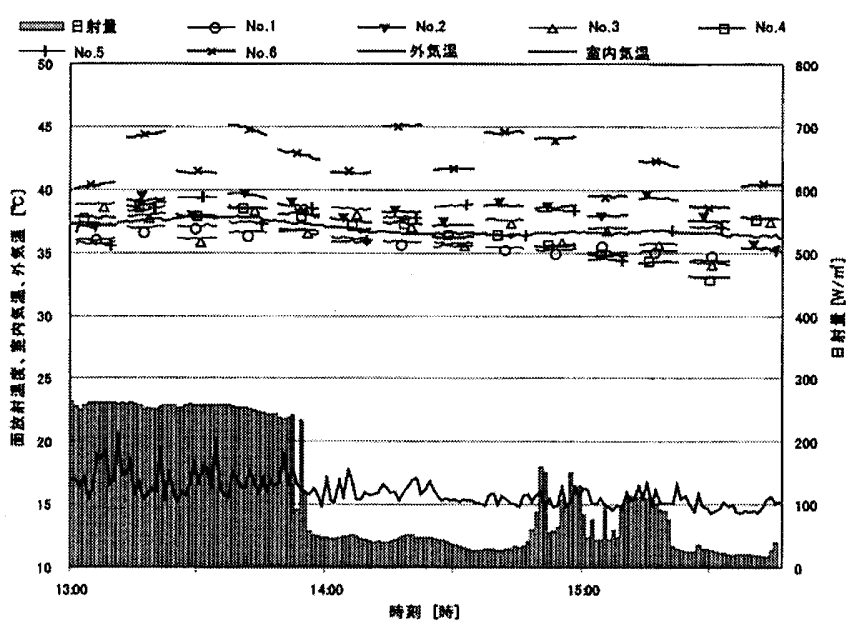

図6 立方体各表面の面放射温度の室内空間分布 （12月 3 日，床上 $100 \mathrm{~cm}, \mathrm{P} 1 \rightarrow \mathrm{P} 25$ の順）

\section{5 正味放射ベクトルの空間分布}

長波長放射の正味の面放射温度について、図7に床上 $50 \mathrm{~cm}$ のべ クトル図、図8に床上 $100 \mathrm{~cm}$ のベクトル図を示す。いずれも図の中 で、左側に水平面内の大きさと方向の図、真ん中に東西方向を含む 垂直面内の大きさと方向の図、右側に南北方向を含む垂直面内の大 きさと方向の図を、それぞれ示している。

一見してわかることは、水平、垂直、どの平面においても、各点 の值を表す記号の散らばる範囲が、床上 $100 \mathrm{~cm}$ より床上 $50 \mathrm{~cm}$ で、 より拡大していることである。これは床上 $100 \mathrm{~cm}$ より床上 $50 \mathrm{~cm}$ で、 床暖房の特徴をよく捉えていることを示唆している。

そこでまず、床上 $50 \mathrm{~cm}$ の水平面（図７中の左図）に注目してみ ると、床面上の東側に位置する 3 測定点 $\mathrm{P} 1(\square) 、 \mathrm{P} 11(+) 、 \mathrm{P} 21(\bigcirc)$ では、值が水平面内の西側に片寄っている。これは、その測定点か ら西側にある床暖房の強い放射を受けていることを意味している。 対照的に西側に位置する 3 測定点 P5 $(\Delta) 、 P 15(\times) 、 P 25(\triangle)$ では、 值が水平面内の東側に片寄っている。これは、その測定点から東側 にある強い放射を受けていることを意味している。同様に南側に位

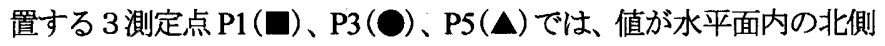
に片寄っている。これは、その測定点から北側にある床暖房の強い 放射を受けていることを意味している。北側に位置する 3 測定点

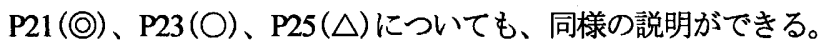

以上の配置にしたがって、床暖房パネルの四隅に近い測定点、南 東隅 P1（四）、南西隅 P5 $(\Delta)$ 、北西隅 P25 $(\triangle)$ 、北東隅 P21(@) で は、それぞれ值が北西寄り、北東寄り、南東寄り、南西寄りに場所 を占めている。床暖房パネルからの偏りの強い放射を受けている、 ということである。床上 $100 \mathrm{~cm}$ の場合は、床上 $50 \mathrm{~cm}$ ほどではない が、しかし同様の傾向が認められる。

床上 $50 \mathrm{~cm}$ の東西方向を含む垂直面では、床上 $100 \mathrm{~cm}$ の場合より も明らかに、下方より強い熱放射を受けているのがわかる。さらに、 水平面で見られたように、東側に位置する $\mathrm{P} 1(\mathbf{E}) 、 \mathrm{P} 11(+) 、 \mathrm{P} 21$ (@) では值が垂直面内の西側に、西側に位置する P5 $(\boldsymbol{\Delta}) 、 \mathrm{P} 15(\times)$ 、 P25( $\triangle)$ では值が垂直面内の東側に片寄っているのがわかる。南北 方向を含む垂直面でも類似の説明ができる。これらの床上 $50 \mathrm{~cm}$ の 垂直面についての説明は、定性的には床上 $100 \mathrm{~cm}$ においても適用で きる。 
測定点 P1 における最初 $(\square)$ と最後 $(\square)$ の測定の間、2 時間 36 分 の時間のずれは、図7、図8を見るかぎりでは、空間分布には影響 を及ぼしていないことがわかる。

このように、立方体正味放射計を用いることによって、床暖房の 加熱面と計測器との位置関係で定まる放射受熱量が的確に、床上 $50 \mathrm{~cm}$ では床上 $100 \mathrm{~cm}$ より明確に捉えることができた。
凡 例

\begin{tabular}{|c|c|c|c|c|c|c|}
\hline P1 & P3 & P 5 & P7 & P 9 & P 11 & P 13 \\
\hline$\square$ & $\bigcirc$ & $\Delta$ & & $\nabla$ & + & $※$ \\
\hline P15 & P17 & P 19 & P 21 & P23 & P25 & P1 \\
\hline$\times$ & $\diamond$ & $\nabla$ & O & $\bigcirc$ & $\triangle$ & $\square$ \\
\hline
\end{tabular}
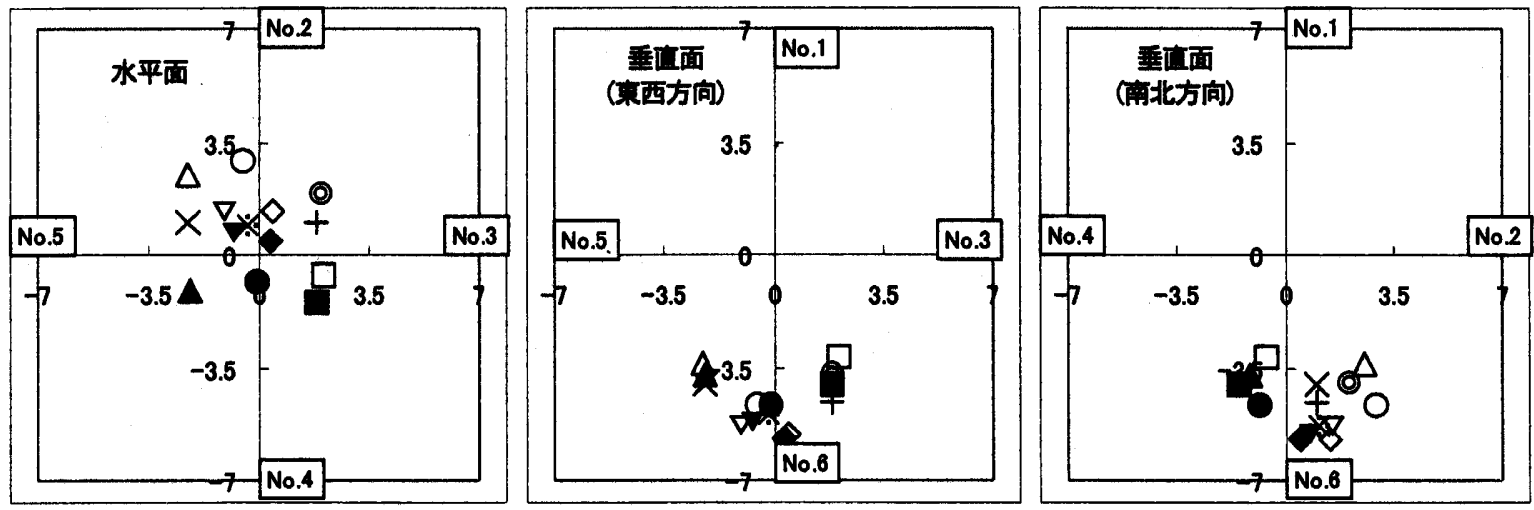

図 7 正味放射ベクトルの平面内分布（12月 3 日, 9:00 11:48, 床上 $50 \mathrm{~cm})[\mathrm{W} / \mathrm{m}]$
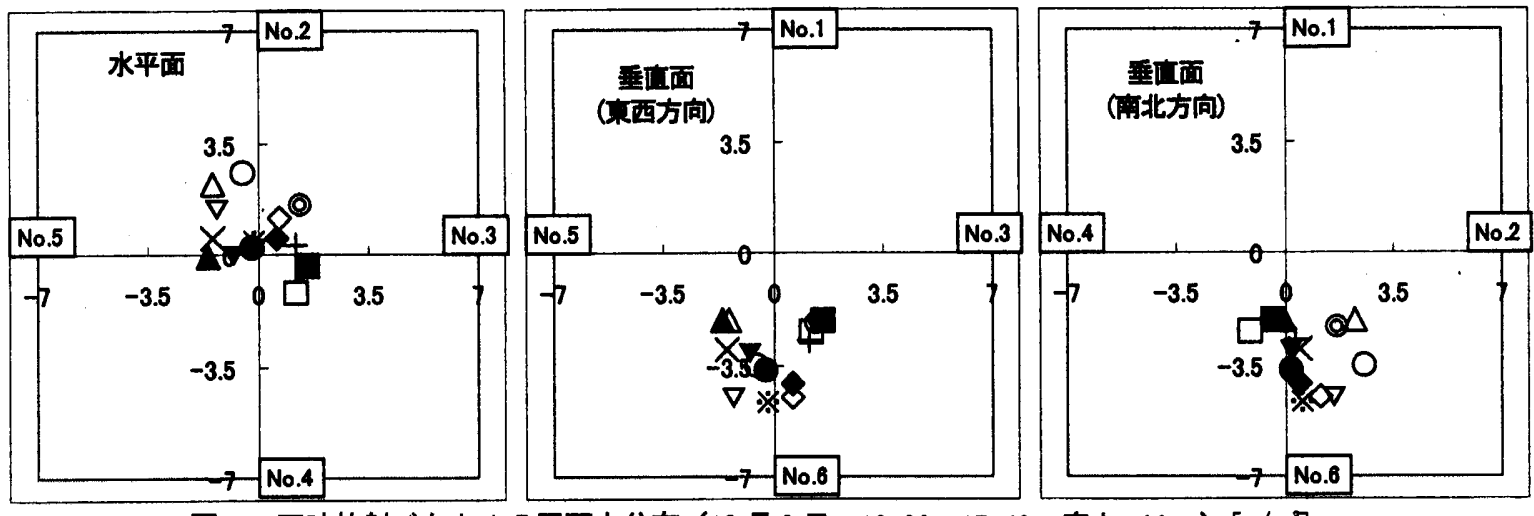

図8 正味放射ベクトルの平面内分布（12 月 3 日，13:00 15:48，床上 $100 \mathrm{~cm})[\mathrm{W} / \mathrm{m}]$

なお、図7、図8の単位表示が熱量 $\left[\mathrm{Wm}^{-2}\right]$ になっていて直感 性に乏しいので、分かりやすい温度の単位 $\left[{ }^{\circ} \mathrm{C}\right]$ で表示しなおすと、 温度が常温の $25.0^{\circ} \mathrm{C}$ のときには、 $6 \mathrm{Wm}^{-2}$ が温度差 $1.0 \mathrm{~K}$ に相当す る。図では最大值の枠が士7 $\mathrm{Wm}^{-2}$ であるから、図7、図8は熱放射 場を精密、かつ詳細に表現していることがわかる。

\section{5. まとめ}

床暖房による室内熱環境の評価に関係する物理的な諸量、とくに 放射の方向性を中心にして、楥房によって生じた熱放射場を精查 することを目的として、立方体正味放射計を用いて電気式床暖房が 施された室内の熱放射場に関して実験を行い、以下の通りの知見を 得た。

(1) 床暖房室内に設置した立方体正味放射計に直達日射が当たる 状態では、日射だけで床暖房の有効面放射温度（暖房床面に対する 面放射温度と室内気温との差) 以上の高い面放射温度を示した。

(2) カーテンを閉鎖した状態では、カーテンを透過した日射の短 波長成分は無視できるほどで、室内の熱放射場の形成には影響を及 ぼさなかった。
(3) カーテンを閉鎖した状態では、カーテンで日射が吸収され、 カーテンから再放射する長波長成分が、熱放射場の形成に影響を及 ぼしていた。

(4) 電気式床暖房の「弱」運転では、4 分ごとの電流の ON/OFF にともなって、立方体正味放射計の各面で值は異なるが、熱放射場 の強弱の変動を忠実に把握することができた。

(5) 室内における測定点の場所による面放射温度の違いは、立方 体の面の向きによる面放射温度の違いほどには大きくはなかった。

（6）立位人体を想定した床上 $100 \mathrm{~cm}$ よりも、床座人体を想定した 床上 $50 \mathrm{~cm}$ において、人体形状に及ぼす床暖房の効果をより明確に 把握することができた。

(7) 面放射温度について、正味放射ベクトルを用いることによっ て、測定点の位置による、床暖房面と測定点との相対的位置関係、 したがって床暖房面と人体との相互の関倸を立体的に把握すること ができた。

[謝辞］実験の遂行には、中道友閣君（学生）の援助を得たこと を記して謝意を表す。 
注 1）立位と椅座位の人体に対する平均放射温度が立方体の6表面の放射受 熱量から求まることは、すでに ISO 7726 (1985) に記載されている ${ }^{11}$ 。 また、人体形状に対応した微小立方体から周囲を見たときの重み係数 (等 価形態係数) の表現については、発表文献 ${ }^{12)}$ がある。

注 2) Fanger, P.O. の人体と周壁面との形態俰数の提案では、立位人体の中心

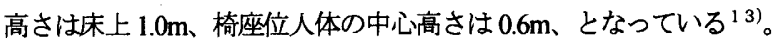
注 3) 立方体正味放射計 ${ }^{5)}$ は、立方体の6表面がそれぞれ独立した測定器の 環境放射計 ${ }^{17}{ }^{7}$ ) で、各表面に入射する（測定面に当たる直前の）日射の 入射量 $\left[\mathrm{Wm}^{-2}\right]$ と、長波長放射の入射量 $\left[\mathrm{Wm}^{-2}\right]$ とが同時に、かつ別々に 約 10 秒の時定数で計ることのできる計測器である。ただし、日射の入射 量を温度 $\left[{ }^{\circ} \mathrm{C}\right] に$ 換算して表示するときは、日射吸収率を指定しなければ ならない。とくに指定がなければ、日射吸収率として 0.5 を使用する。

注4）日射の効果を温度 $\left[{ }^{\circ} \mathrm{C}\right]$ で表示するには、一般には等価気温 ${ }^{14)}$ を用い る。過去に、Nakamura (1983) ${ }^{15)}$ 、Nakamura et al (2003) ${ }^{16)}$ では、それを 用いた。しかし、等価気温で表す場合は、長波長放射の表示式中に気温 が入っているので、時々刻々に変化する気温のため、気温によって変動 するはずのない長波長放射が、等価気温でははげしく変動してしまい、 見づらい結果となる。そのため今回は等価気温ではなく、面放射温度で 表すことを考えた。面放射温度で表すと気温変動とは関係なく、安定し た変動を示すようになった。图2がその例である。

なお、日射による面放射温度と日射の等価気温との違いは大小関係に あり、放射熱伝達率と対流熱伝達率とが相等しいとすれば、日射による 面放射温度は日射の等価気温の 2 倍の值となる。日射吸収率は両者で同 一である。

注 5）採用通知時に查読子より修正意見があり、「この立方体正味放射計に、 気が付かないうちに日射が当たっている場合には、適切な長波長放射環 境評価は困難になってくると思われますので、まとめの(1)での表現も、 本測定装置の適用範囲や注意事項として述べるべきかと思います。」とあ りますが、遺憾ながら文意が理解できません。誤解ではないかと、対応 に苦慮しています。

繰り返しますが、立方体正味放射計の性能については、すでに文献ら で、さらには上記の注 3）で述べた「気がつく、つかないに関係なく 日射量も長波長放射量も、同時に、かつ別々に測ることのできる計器で ある。日射の測定システムと長波長放射の測定システムは、互いに独立 なのである。相互に影響しあうことはない。

そのことは、図2にも表れている。カーテンを閉鎖した 11:13 を境に して、日射量は急激に減少しているが、長波長放射量は、立方体の南向 き面と下向き面でわずかに減少したに過ぎない。カーテン開放時は空ガ ラスの高くなった温度と、床の日射が当たって高くなった温度を感知し、 カーテンが閉銷されるとカーテン地の低い温度と、床の日射がなくなっ て低くなりだした温度を感知したことを示している。日射か長波長放射 か、どちらか一方の值に引きずられて他方の值が異常を示す、というこ とはない。当然と思われる結果が、測定值に表れているのである。

強いて言えば、センサーが 3cm 四方の大きさをもっているので、日射 が当たるときに $3 \mathrm{~cm}$ 四方全面に当たらず、部分的にしか当たらないとき には、正しく測れないことがある。しかしこれは例えば、一定の視野を もった放射計で計るときに、視野に入る部分全体が一様な温度でないと 正しく測れないことと同類である。注意事項として述べるほどのもので はなく、放射計測では当然の、初歩的な常識である。

それに関連して、屋外の木漏れ日の測定などでは、日射のために測定
対象物がキラキラと輝いて日射量がはげしく変動するので、6秒ごと 60 回の測定で 10 分間の、十分に時間をかけた平均で評価するようにしてい る。このように、測定に際して特別の支障はない。

以上の論述のとおり、「まめ」の(1)の表現については、修正には及ば ないと了解する。しかしただ一つ、理解の一助になるかもしれないので 関連する参考文献を 1 件 ${ }^{17)}$ 追加する。

\section{[参考文献]}

1) Siegel, R. and Howell, J.R.: Thermal Radiation Heat Transfer, Mc-Graw Hill, 1972. 2) McIntyre, D. A : The thermal radiation field, Building Science, Vol.9, p.247, 1973.

3）中村泰人：建築都市空間内の人体に対する熱放射場の表現方法について、 日本建筮学会計画系論文報告集、第376 号、pp.29-35, 1987.6

4) Ozisik, M.N. : Radiative Transfer and Interactions with Conduction and Convection, John Wiley, 1973.

5) 中村泰人、辻原万規彦、西村浩一、香川治美 : 環境放射計からなる立方体 正味放射計の構成と較正、日本建築学会環境系論文集、第 580 号、pp.15-21, 2004.6

6) 吉田治典、郡 公子 : サステイナブル建築のための熱嬛境設計と熱性能㭘 証の技術、第 7 回 環境工学シンポジウム「環境工学の未来を拓く研究と 技術開発」資料、日本建築学会、2004.1.29

7) 百家裕季、中村泰人、岡本孝美、天川章史 : 床暖房による室内の放射熱分 布（その1 計測)、日本建築学会学術講演梗概集、環境系 D-2、pp.29-30, 2004.8

8) 中村泰人：建築環境計測における気温測定のための双対感温素子の検討、 日本建築学会近畿支部研究報告集[計画系]、pp.57-60, 1977.5

9) ISO 7726: Ergonomics of the thermal environment. Instruments for measuring physical quantities. Geneva: International Standards Organization, 1998.

10) 前田敏男 : 伝熱学、新訂建築学大系 8 、「音・光・熱- 空気・色小、彰国 社、p.337, 1969.5

11) Parsons, $K$ : Human Thermal Environment, $2^{\text {nd }}$ ed., Taylor \& Francis, London and New York, 2003, p.101

12）中村泰人、武田 諭: 人体形状に対応した微小立方体加見る等価形態 係数、その 1 等価形態係数の表現、日本建築学会大会学術講演梗概集、 pp.989-900, 1992.8

13) 前掲 11) pp.99-100.

14) 前揭 10) p.345.

15) Nakamura, $Y$ : : Measurements of Thermal Radiation Fields on Occupied Space in a Room Using the Cubic Radiant Flux Detector and Personal Computer, Proceedings of the Fourth International Symposium on the Use of Computers for Environmental Engineering Related to Buildings, 1983, Tokyo, pp.66-71.

16) Nakamura, Y., Tsujihara, M. and Kagawa, H. : Observation of Solar and Long Wave Radiation Fields in Urban Canyon by Using a Cubic Radiometer, Proceedings of the Fifth International Conference on Urban Climate, 1-5 September 2003, Lodz, Poland, Vol.2, pp.397-400.

17) 環境放射束計 特許公開平 11-173911

（2004年 12 月 8 日原稿受理， 2005 年 5 月 6 日採用決定） 